Journal of Business \& Management (COES\&RJ-JBM)

ISSN (E): 2306-7179 ISSN (P): 2306-8043

Publisher: Centre of Excellence for Scientific \& Research Journalism, COES\&RJ LLC

Online Publication Date \& Issue: 1st January 2018, Vol.6, No.1, January 2018

https://doi.org/10.25255/jbm.2018.6.1.84.97

\title{
Quality Management System's (QMS) impact on organizational performance of the college academic deans: a basis for continual improvement
}

\author{
Erwin B. Quendangan,DBA \\ Ferdinand C. Somido,PhD \\ Susana C. Bautista, EdD \\ Pedrito Jose V. Bermudo, PhD \\ Antonio D. Yango,PhD \\ Leomar S. Galicia, PhD
}

\begin{abstract}
:
Among the most important characteristics that distinguish a community from other communities is its ability to manage institutions and vital programs, not only effectively, but fairly innovative. This descriptive study assessed the elements of quality management system as performed by the college academic deans at colleges/universities located in Quezon City, Philippines where they were connected. The key issues the study examined include the impact of the elements of quality management as performed by the college/university academic deans that affect their performances.

Keywords:

quality management system, organizational performance, continual improvement

\section{Citation:}

Quendangan, Erwin B.; Somido, Ferinand C.; Bautista, Susana C.; Bermudo, Pedrito Jose V.; Yango, Antonio D.; Galicia, Leomar S.; (2018); Quality Management System's (QMS) impact on organizational performance of the college academic deans: a basis for continual improvement; Journal of Business \& Management (COES\&RJ-JBM) Vol.6,No.1,pp.84-97, https://doi.org/10.25255/jbm.2018.6.1.84.97.
\end{abstract}

This work is licensed under a Creative Commons Attribution 4.0 International License. 


\section{Introduction}

Quality management can be traced all the way back to the middle ages. Work completed by journeymen and apprentices were evaluated and inspected by the skilled worker to ensure that quality standards were met in all aspects of the finished product, ensuring satisfaction of the buyer. And while the history of quality management has gone through a number of changes since that time, the end goal is still the same.

According to E.W. Deming (2000), it was during the 1920's when quality management systems started to surface. While the focus of quality management was still on the end product, it was the first time that statistical theory was applied to product quality control.

The organization controls the various phases of a project. It is amazing how much scientific management is still around and exerts influence on modern management. In many respects, modern managerial practice grows largely out of Taylor's classical approach. For example, the Gantt Chart invented by Henry Gantt, is still widely used today according to Kanigel (2010).

Colleges and Universities, including AMA Education System, are tertiary institutions that typically offer one or a few specialized courses, for example, in the sciences or in Liberal Arts, or in specific professional courses, such as Engineering, Nursing, Computing, or Maritime Studies.

This study aimed to determine the quality management system's (QMS) impact on organizational performance of the college academic deans as basis for continual improvement of the selected Higher Education Institutions in Quezon City. Specifically, this study sought answers to the following questions:What is the profile of college academic deans in terms of:Gender,CivilStatus, Highest Educational Attainment, and Length of Service;What are the elements of Quality Management System that will have an impact on college academic deans' organizational performance in terms of:Administration and Management, Academic Qualification, Leadership, Customer Focus, Institutional and Strategic Planning, and Policy: Resources which include People, Facilities, Finance, and Machinery/Equipment: and Networking and Linkages such as Community Outreach Involvement,Business and Industry Partnerships, and Research.

In order to be guided in the research work, a framework is provided to show the flow of the research problems towards its objectives. The framework illustrates the conceptual of the respondents to determine the quality dimensions that establish quality management towards the administration, organization, faculty, and students. 


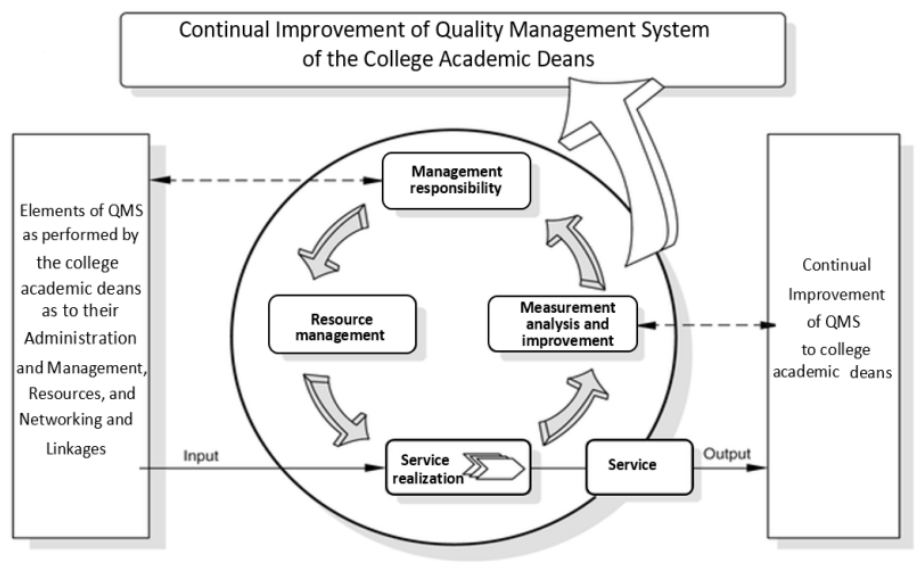

Figure 1

Conceptual Framework of the Study

Figure 1 shows the characteristic of ISO 9001:2008 which is the process approach that promotes the adoption of an International Standard when developing, implementing, and improving the effectiveness of a quality management system, to enhance customer satisfaction by meeting customer requirements (Frost, ISO Survey, 2011).This figure shows the conceptual framework of the study which began by determining the best performances and practices of academic deans as to their administration and management, resources, and networking and linkages in the academic organization as basis for the continual improvement to quality service.

\section{Methods}

This study used the descriptive survey method. The descriptive method is a research wherein events are recorded, described, interpreted, analyzed and compared (Castillo, 2002). Its objective is to describe systematically a situation, condition or area of interest factually and accurately. Descriptive designs include observations, surveys and interviews, standardized tests, and case studies. It is used to determine the Quality Management system of the College Academic Deans from the selected Higher Education Institutions in Quezon City.

The respondents of the study were the College Academic Deans of some selected Higher Education Institutions ( $\mathrm{HEI}$ ), including AMA Education System, in Quezon City.The profile of the respondents where categorized as to gender, civil status, highest educational attainment, and length of service.The sampling technique that was used in this study in selecting the respondents is the purposive sampling. The researcher had selected the academic deans of some HEls in Quezon City to provide input into the investigation.This phase involved the gathering of data and compilation of detailed information collected. The use of data gathering instrument is to obtain data that are intended for collecting sufficient information to complete the study and investigation. The researcher made use 
of the instruments such as questionnaire, observation, interview, library technique, and surfing the internet.

\section{Results}

The results which are presented in textual and tabular forms sought answers to the given problems:

1. The profile of college academic deans

Table 1 shows the percentage distribution of the respondents according to gender.

Table 1

Respondents Profile According to Gender

\begin{tabular}{|c|c|c|}
\hline Gender & Frequency & Percentage \\
\hline Male & 28 & 56 \\
\hline Female & 22 & 44 \\
\hline TOTAL & $\mathbf{5 0}$ & $\mathbf{1 0 0}$ \\
\hline
\end{tabular}

As gleaned from the table, it indicated that there were 28 respondents out of 50 or 56 percent were males. Female had 22 respondents or 44 percent. The data further revealed that the male respondents outnumbered the female respondents of 6 or 12 percent. This shows that nowadays in the higher education institutions in Quezon City, majority of the college academic deanship positions are headed by males.

Table 2 shows the percentage distribution of the respondents according to civil status.

Table 2

Respondents Profile According to Civil Status

\begin{tabular}{|c|c|c|}
\hline Civil Status & Frequency & Percentage \\
\hline Single & 15 & 30 \\
\hline Married & 35 & 70 \\
\hline Widow & 0 & 0 \\
\hline TOTAL & $\mathbf{5 0}$ & $\mathbf{1 0 0}$ \\
\hline
\end{tabular}

As presented in the table 2, it showed that the married respondents had 35 or 70 percent out of 50 total respondents. Respondents who were single had only 15 or 30 percent. This further showed that most of the respondents were married.

Table 3 shows the profile distribution of the respondents according to educational attainment.

Table 3

Profile of the Respondents According to Highest Educational Attainment

\begin{tabular}{|c|c|c|}
\hline Highest Educational Attainment & Frequency & Percentage \\
\hline Masters Degree & 38 & 76 \\
\hline Doctorate Degree & 12 & 24 \\
\hline TOTAL & $\mathbf{5 0}$ & $\mathbf{1 0 0}$ \\
\hline
\end{tabular}

As observed in table 3, most of the respondents were Master's Degree holders with 38 or 76 percent. Only 12 out of 50 total respondents or 24 percent were just Doctorate 
Quality Management System's (QMS) impact on organizational performance .....

Degree graduates. It further showed that the academic deanship positions of the Higher Education Institutions in Quezon City were supervised by Master's Degree holders.

Table 4 shows the profile distribution of the respondents according to length of service.

Table 4

Profile of the Respondents According to Length of Service

\begin{tabular}{|c|c|c|}
\hline Length of Service & Frequency & Percentage \\
\hline $0-5$ years & 19 & 38 \\
\hline $6-10$ years & 14 & 28 \\
\hline $11-15$ years & 9 & 18 \\
\hline $20-25$ years & 7 & 14 \\
\hline 26 years and beyond & 1 & 2 \\
\hline TOTAL & $\mathbf{5 0}$ & $\mathbf{1 0 0}$ \\
\hline
\end{tabular}

Table 4 discussed the results for the length of time of the academic deans in their current position ranged from less than one year to twenty-six (26) years and beyond.Survey results indicated that 19 or forty-five percent (45.0\%) respondents had been in their position five years or less. It was followed by 14 or twenty-eight percent $(28.0 \%)$ had served in their position between 6 to 10 years. Followed by nine or eighteen percent (18.0\%) of the respondents served the position between 11 to 15 years. Seven respondents or fourteen percent (14.0\%) were in the bracket between $20-25$ years. With these four groups combined, the results showed that $98.0 \%$ of the respondents had served in theircurrent position twenty-five years or less. The remaining respondent had been in his position for twenty-six (26) years and beyond, or $2.0 \%$ of the total respondents.

2. The elements of quality management system that will have an impact on college academic deans' organizational performance in terms of administration and management.

Table 5

Assessment of Respondents in terms of Organization and Management

\begin{tabular}{|l|c|c|c|}
\hline \multicolumn{1}{|c|}{$\begin{array}{c}\text { Administration and } \\
\text { Management }\end{array}$} & $\begin{array}{c}\text { Weighted } \\
\text { Mean }\end{array}$ & $\begin{array}{c}\text { Verbal } \\
\text { Interpretation }\end{array}$ & Rank \\
\hline 1. Academic Qualification & 4.0 & Very Important & 4 \\
\hline 2. Leadership & 4.6 & $\begin{array}{l}\text { Extremely } \\
\text { Important }\end{array}$ & 2 \\
\hline 3. Customer Focus & 3.7 & Very Important & 5 \\
\hline $\begin{array}{l}\text { 4. Institutional and Strategic } \\
\text { Planning }\end{array}$ & 4.7 & $\begin{array}{l}\text { Extremely } \\
\text { Important }\end{array}$ & 1 \\
\hline 5. Policy & 4.1 & Very Important & 3 \\
\hline \multicolumn{1}{|c|}{ Over-All Weighted Mean } & 4.22 & \multicolumn{2}{|c|}{ Very Important } \\
\hline
\end{tabular}

Table 5 revealed the impact of the elements of quality management system of the college academic deans' performance as to their administration and management in the 
academic organization. The result of Table 5 indicated that Institutional and Strategic Planning was ranked as the number one most important element of quality management system performed by academic deans with a mean score of 4.7 and with a verbal interpretation of "Extremely Important". The mean score was achieved as a result of 15 respondents selecting " 4 "=Very important, and 35 selecting " 5 "=Extremely Important as to their estimation of how important they believe these elements of QMS are to possess.

The second highest scoring element was Leadership with a mean score of 4.6 and interpreted as "Very Important. Presidents and vice presidents rely heavily on academic deans to lead their college and to help the university forge ahead. In contrast, faculty members expect academic deans to support their discipline specific initiatives in the areas of research and teaching. Students rely on academic deans to ensure quality programs, course offerings, and student support..

Third highest scoring element of QMS as to academic deans' administration and management was Policy with a mean score of 4.1 and verbally interpreted as Very Important. Aside from the rules and regulations imposed by the academic institutions, it was also important to abide by the policies formed by the academic deans. The academic deans make ethical and data-driven decisions that promote the overall progress of the College and resolve crises and problems that threaten to impede progress in a timely manner; recognize and analyze problems, evaluate reasonable solutions, take or recommend problem resolution action, and implement appropriate immediate and systemic changes to avoid problem re-occurrence; demonstrate decisiveness and discipline in problem solving and crisis management; provide guidance to faculty in decision making and problem solving; assume responsibility for all decisions made within the College.

Forth element of QMS as to academic deans' administration and management was Academic Qualification with a mean score of 3.9 and interpreted as Very Important. Academic qualification of a dean was significant in the organization that had both an academic knowledge of the job athand and the real-world skills to perform the tasks required. It was essential to exercise sufficient degree in supervising the academic organization.

Customer Focus was the last element of QMS as to the administration and management of academic deans with a mean score of 3.7 and verbally interpreted as Very Important. The orientation of the academic dean toward serving its clients' needs was necessary. This was sometimes conducted through Students Satisfaction Survey, an element of institutional assessment since it was related to student retention and success. Over-all weighted mean of the respondent's elements of quality management system performed by academic deans as to their management and organization was 4.2 and interpreted as Very Important.

According to Gmelch et al., (2011); Montez, Wolverton, \&Gmelch (2002); Tucker \& Bryan, $1(988)$, research has found the responsibilities of the academic deanship can create role ambiguity and cause conflict due to the lack of a clear understanding of the duties and 
responsibilities. Ambiguity arises when academic deans do not have adequate information to perform effectively. Conflict, could be created when expectations differ from those in the college to those in administration (Wolverton\&Gmelch, 2002). .

As Boyatzis (1982) asserted, "organizations need managers to be able to reach their objectives" (p. 1), but organizations must have "competent managers to be able to reach these objectives both efficiently and effectively" (p. 1). Competencies are what Boyatzis considered "certain characteristics or abilities" (p. 12), in which one accomplishes or achieves in the job. Boyatzis explained that managers without the necessary competencies could go into a new position and maintain operations until such time when decisions or actions resulted in ineffective performance.

3. The elements of Quality Management System that will have an impact on college academic deans' organizational performance in terms of resources.

Table 6

Assessment of Respondents in terms of Resources

\begin{tabular}{|c|c|c|c|}
\hline Resources & $\begin{array}{c}\text { Weighted } \\
\text { Mean }\end{array}$ & $\begin{array}{c}\text { Verbal } \\
\text { Interpretation }\end{array}$ & Rank \\
\hline People & 4.2 & Very Important & 2 \\
\hline Facilities & 3.9 & Very Important & 4 \\
\hline Finances & 4.5 & $\begin{array}{c}\text { Extremely } \\
\text { Important }\end{array}$ & 1 \\
\hline Machinery/Equipment & 4.0 & Very Important & 3 \\
\hline Over-All Weighted Mean & $\mathbf{4 . 1 5}$ & \multicolumn{2}{|c}{ Very Important } \\
\hline
\end{tabular}

Table 6 revealed the elements of QMS of academic deans as to the resources in managing the organization.

The first in rank element of QMS with a mean score of 4.5 was Finances and interpreted as Very Important. Colleges and universities faced a combination of acute state revenue constraints with having to compete with social services along with the ongoing changes in the public's perception toward higher education, all of which require continued state support for higher education (Del Favero, 2005; McGuinness, 2011; Rosser et al., 2003; Tucker \& Bryan, 1988).

Skills in budget management were important for academic leaders when addressing the needs of the academic programs and in trying to balance the competing priorities from various contingency groups (Del Favero, 2005; Rosser et al., 2003; Tucker \& Bryan, 1988). However, budget management is often dependent on other administrative functions such as having to solicit external funding in support of academic programs, and the planning process involved with resource allocation. With an increased demand for budget knowledge and experience, academic administrators risk having limited capacity to respond to critics who claim that resources are not being allocated to the areas in most need (Wolverton\&Gmelch, 2002). Effectively, academic deans' inexperience in 
these matters can be perceived as disproportionate concern about money issues as opposed to academic matters resulting in criticism for not addressing funding requests for specific disciplines.

Second highest rank was People with a mean score of 4.2 and interpreted as "Very Important. This conveyed about all aspects of the college/department to internal audiences that include students, faculty, and staff, and other special interest groups. Proper dissemination of tasks to staff and good communication skills as performed by academic deans to the overall conduct of job responsibilities in such a way that performance is efficient and productive. Similar to the literature (Gmelch, 2000; Gmelch et al., 2011), the role of academic dean was referred to as "kind of a multifaceted job partially internal, partially external".

Wolverton and Gmelch (2002) maintained that, "in higher education, we make a very large assumption that the deans hired by colleges possess the skills and aptitudes they need to be successful" (p. 10). Nonetheless, deans can learn skills, but professional development activities are how deans attain aptitudes.

Under Gmelch et al. (2011) seasonsof academic deans, professional development was identified as just one part of their overall development, because effective leadership occurs over time by providing a rich experience of the organizational structure. Interaction with faculty, staff, and students is critical for academic deans; consequently, having strong people skills is a must in order to listen and address issues from the various constituents.

Third highest rank as an element of quality management system performed by academic deans in the organization was Machinery/Equipment with a weighted mean of 4.0 and verbally interpreted as "Very Important". The tangible properties of the school that were used in the operations of the business are essential things to run the transactions in the organization.

Forth and last resource as an element of QMS performed by deans was Facilities with a weighted mean of 3.9 and verbally interpreted as Very Important. When maintaining a school, bricks and mortar were not only be paid, but also student and staff well-being. Effective school maintenance protected capital investment, ensured the health and safety of our children, and supported educational performance.

Effectively, academic deans are already participating in professional organizations in their discipline, accreditation, and other professional conferences to keep abreast of new developments to facilitate better services towards the whole academic community. (English, 1997;Gmelch et al., 2011).

Over-all weighted mean of elements of QMS as executed by academic deans in their respective organizations as to Resources was 4.15 and verbally interpreted as Very Important. 
4. The elements of Quality Management System that will have an impact on college academic deans' organizational performance in terms of networking and linkages.

When determining how to cultivate administrative leadership capacity for academic deans, the best source of information is from those who are serving, or have served in the role of academic dean (Gmelch et al, 2011).

Table 7

Assessment of Respondents in terms of Networking and Linkages

\begin{tabular}{|c|c|c|c|}
\hline Networking and Linkages & $\begin{array}{c}\text { Weighted } \\
\text { Mean }\end{array}$ & $\begin{array}{c}\text { Verbal } \\
\text { Interpretatio } \\
\mathbf{n}\end{array}$ & Rank \\
\hline Community Outreach Involvement & 3.9 & $\begin{array}{c}\text { Very } \\
\text { Important }\end{array}$ & 3 \\
\hline Business and Industry Partnership & 4.6 & $\begin{array}{c}\text { Extremely } \\
\text { Important }\end{array}$ & 1 \\
\hline Research & 4.0 & $\begin{array}{c}\text { Very } \\
\text { Important }\end{array}$ & 2 \\
\hline Over-All Weighted Mean & $\mathbf{4 . 1 6}$ & \multicolumn{2}{|c|}{ Very Important } \\
\hline
\end{tabular}

Table 7 disclosed the various elements of quality management system performed by the academic deans as to the networking and linkages.

First in rank element of QMS as to the networking and linkages was Business and Industry Partnership with a weighted mean of 4.6 and verbally interpreted as Extremely Important.

Academic deans performed a vital role in cultivating external relationships, building a support group, and pursuing donors who believe in the mission and vision of their college. The various groups involved in the external relations are usually made up of alumni, parents, community leaders, legislatures, and business leaders. Because of the importance and sometimes high profile of fundraising, which are critical external functions for both the college and the university, the endeavors are usually assigned to the university president or the development officer (Tucker \& Bryan, 1988).

Next in rank, as an element of QMS executed by academic deans in the organization as to their networking and linkages, was Community Outreach Involvement. As part of the school's commitment to corporate social responsibility, the entire academic community, headed by the academic deans, must regularly involve themselves to any organized community outreach activities to develop rapport and sustain community relations.

Third and last rank element of QMS as to Networking and Linkages, which was carried out by the academic deans in performing their duties and responsibilities, was Research. Aside from the researches provided by the deans, he/she must also encourage faculty and/or staff to initiate collaborative research to improve their respective services towards the department, student's academic performance, and the school as a whole. 
Institutions of higher education also have unique cultures different from other organizations because of their ethos, rituals, dynamic diverse groups, and the many challenges facing senior leaders (Kezar et al., 2002; Peterson \& Spencer, 1990; Tierney, 1988). Institutional culture is not just limited to the university level; instead, being ubiquitous it varies in magnitude and intensity depending on the unit, players involved, and complexity. The term organizational "climate," which is often used interchangeably with culture, is the "current common patterns of important dimension of organizational life or its members' perceptions of and attitudes toward those dimensions" (Peterson \& Spencer, 1990, p. 7). Understanding culture will not provide solutions to institutional challenges, but it will provide a "critical insight" (Tierney, 1988, p. 5) for making informed decisions. Tierney (1988) asserted that administrators are responsible for keeping the instances of cultural outbursts at bay, while working toward cultivating a shared vision and common goals. An understanding of organizational culture encourages educational leaders to "consider why different groups in the organization hold varying perceptions about institutional performance" (Tierney, 1988, p. 6).

As to Networking and Linkages, the over-all mean of the academic dean's performance as elements of QMS in performing quality management system was 4.16 and interpreted as Very Important.

Table 8

Summary of Elements of Quality Management System's Impact on College Academic Deans' Organizational Performance

\begin{tabular}{|c|c|c|c|}
\hline $\begin{array}{c}\text { Elements of Quality } \\
\text { Management System }\end{array}$ & $\begin{array}{c}\text { Weighted } \\
\text { Mean }\end{array}$ & $\begin{array}{c}\text { Verbal } \\
\text { Interpretation }\end{array}$ & Rank \\
\hline $\begin{array}{l}\text { 1. Organization and } \\
\text { Management }\end{array}$ & 4.22 & Very Imporatnt & 1 \\
\hline 2. Resources & 4.15 & Very Important & 3 \\
\hline 3. Networking and Linkages & 4.16 & Very Important & 2 \\
\hline Over-All Weighted Mean & 4.17 & \multicolumn{2}{|c|}{ Very Important } \\
\hline
\end{tabular}

Effectiveness is necessary associated with the notion of quality. Quality is a perfection standard by which an organization decides whether its practices conform to its objectives and strategies in a way that meets the clientele's need according to Bone and Griggs (2008).

Table 8 showed that Organization and Management was the most vital element of QMS as performed by the academic deans with a weighted mean of 4.22 and verbally interpreted as Very Important. This proved that academic deans sustained the development, administration, and promotion of the academic programs and academic support functions of the college/department including international programs.

Networking and Linkages ranked second with a weighted mean of 4.16 and verbal interpretation of Very important. Continuous development of external relationships 


\section{Quality Management System's (QMS) impact on organizational performance .....}

for the purposes of (1) enhancing student placement opportunities; (2) providing meaningful community outreach opportunities for students and faculty; and (3) engaging with business partnerships.

Resources ranked third with a mean score of 4.15 and verbally interpreted as Very Important.The availability and allocation of resources for the academic institution and the school as a whole affect its quality and results. Understanding the resources associated with professional learning and actively and accurately tracking them facilitates better decisions about and increased quality and results of professional learning. The over-all weighted mean of the different elements of QMS as performed by academic deans was 4.17 and verbally interpreted as Very Important.

\section{Discussion}

The researcher came up with the following summary of findings as taken from the data gathered, interpreted, and analyzed. The most significant findings that affect the Quality Management System towards the administration, organization, faculty, and students are summarized as follows: as to the Profile of Respondents:majority of the respondents were males, weremarried,almost all of the respondents were Master Degree holders, and were in the service from zero (0) to five (5) years. As to the Assessment of the respondents as to the impact of quality management system as basis to continual improvement In terms of organization and administration: Academic Qualification The ability to exercise sufficient degree in supervising the academic organization, Institutional and Strategic Planning - expressed as the ability to establish short and long -term goals and objectives, and procedures to achieve them and to change them as circumstances warrant, Customer Focus - The orientation of the academic organization's dean toward serving its clients' needs, Leadership - described as the ability to influence people so that they strive willingly and enthusiastically to help accomplish individual and institutional goals, Policy - explained as the ability to understand and provide oversight in the development and/or revision policies, procedures, and operational activities, both internally and externally, of the department.

As to the organization and management of academic deans in the service, it was revealed that Institutional and Strategic Planning was ranked as the number one most important element of QMS with a mean score of 4.7 and with a verbal interpretation of "Extremely Important". Customer Focus was the last element of QMS with a mean score of 3.7 and verbally interpreted as Very important.With regard to Assessment of the respondents as to the impact of quality management system as basis to continual improvement in terms of resources: People - Referred to the individuals who demonstrated capacity to promote the public interest with identifiable leadership, Facilities - Referred to the school's physical environment that is comfortable, safe, secure, accessible, well illuminated, well ventilated, and aesthetically pleasing atmosphere, Finance Management - described as the ability to develop and administer budgets, acquire funding to operate the college, and the ability to formulate financial plans for the future. It Includes department budgets and capital expenses, and Machinery/Equipment Referred to the tangible properties of the school that is used in the operations of the business. 
As to the resources of the college academic deans in leading the academic organization, Finances was ranked number one with a mean score of 4.5 and verbally interpreted as Very Important. Budget development was necessary to estimate the funds required to operate the academic organization's educational and support programs intended for every school year. In terms of the Assessment of the respondents as to the impact of quality management system as basis to continual improvement in terms of networking and linkages: Community Outreach Involvement - Referred to the exposure to the conditions and needs of the wider community, especially to those of disadvantaged sectors,Business and Industry Partnerships - explained as the ability to successfully identify, develop, and implement a partnership with business and/or industry in order to help the department, campus, and/or college as a whole, Research - Referred to the study of materials and sources developed by the academic deans in order to establish facts and reach new conclusions for continuous improvement of the organization.Business and Industry Partnerships was the top most needed element of QMS in terms of networking and linkages.

In view of the summary of findings and conclusions, the researcher offers the following suggested recommendations: The academic deans of higher education institutions in Quezon City must realize that education is a continuous process. Hence, may convince themselves to go further schooling to support and maintain the good social order towards the co-employees, to enhance personal and professional growth, to facilitate change in a dynamic society, and to improve more their professional quality management practices as service providers in the academic organization. As Albert Einstein once suggested that "Intellectual growth should commence at birth and cease only at death", The commitment of the academic deans of HEls in Quezon City towards the organization is very important matter to achieve their desired goals. Employment setting such as the Civil Status must not affect the hiring decisions and introduce unwanted bias. As long as they are innovative in determining the quality dimensions of QMS needed to prepare for, and be successful in the role of academic deans, HEls in Quezon City must formally recognize tenure/job security in some ways. Forms of recognition programs must be regularly organized and implemented (aside from the benefits mandated by the Law) to hold the leaving out of employees specifically the academic deans in the academic organization, Academic deans of HEls at Quezon City must regularly carry out the elements of Quality Management System in their work to increase high standards of performance to which they provide programs and services. They must sustain the top ranks quality service dimensions as identified in this study in terms of organization and management, resources, and network and linkages. These elements of QMS must be provided and rendered to ensure quality outcomes but exert more efforts too to strengthen its identified weaknesses, The academic deans should enhance fair practices and increase the active and effective engagement of all academic community that may not negatively affect the workforce in the organization. Typically, the task of assembling a quality team starts at the top. There is a need to develop recognition programs for all the academic deans for them to feel good about their accomplishments, and Future researchers are encouraged to rethink in providing the support in developing the administrative competencies and fortitude to serve in the challenging role of academic deans. 


\section{References}

Al-Khatib, A., (2011). Total Quality Mangement: Applications in university management.Journal of the association of Arab universities, the number specialist No.3, 83-122. Yarmouk University, Jordan

Boyatzis, R. E. (1982). The competent manager: A model for effective performance. New York: John Wiley \& Sons.

Boyatzis, R. E. (2008). Competencies in the 21st century. Journal of Management Development, 27(1), 5-12.doi:10.1108/0262171081

Bright, D. F., \& Richards, M. P. (2001). The academic deanship: Individual careers and institutional roles (1st ed). San Francisco: Jossey-Bass.

Del Favero, M. (2005). The social dimension of academic discipline as a discriminator of academic deans' administrative behaviors. Review ofHigher Education, 29(1), 69-96.

Deming, W. Edwards, (2000). The New Economics for Industry, Government, Education, 2nd edition. Cambridge, MA: The MIT Press

English, R. A. (1997). The deanship as a cross-cultural experience. New Directions for Higher Education, (98), 21-29.

Gmelch, W. H. (2000). Leadership succession: How new deans take charge and learn the job. Journal of Leadership Studies, 7(3), 68-87.

Gmelch, W. H., Hopkins, D., \& Damico, S. B. (2011). Seasons of a dean's life: Understanding the role and building leadership capacity (1st ed). Sterling,VA: Stylus Pub.

Kanigel, Robert, (2010). The One Best Way: Frederick Winslow Taylor and the Enigma of Efficiency. Cambridge, MA: The MIT Press

Kezar, A. J., \&Eckel, P. D. (2002). The effect of institutional culture on change strategies in higher education: Universal principles or culturally responsive concepts? The Journal of Higher Education, 73(4), 435-460.

McGuinness, Jr., A. C. (2011). The states and higher education. In P. G. Altbach, P. J. Gumport, \& R. O. Berdahl (Eds.), American Higher Education in theTwenty-First Century: Social, Political, and Economic Challenges ( $3^{\text {rd }}$ ed.). Baltimore, Maryland: The Johns Hopkins University Press.

Smith, Z. A., \&Wolverton, M. (2010). Higher education leadership competencies: Quantitatively refining a qualitative model. Journal of Leadership \&Organizational Studies, 17(1), 61-70. 
Tierney, W. G. (1988). Organizational culture in higher education. Journal of Higher Education, 59(1), 1-21.

Travers, Max, (2007). The New Bureaucracy: Quality Assurance and Its Critics. Bristol UK: The Policy Press University of Bristol

Tucker, A., \& Bryan, R. A. (1988). The academic dean: Dove, dragon, and diplomat. New York: American Council on Education: Macmillan.

Tucker, A., \& Bryan, R. A. (1991). The academic dean: Dove, dragon, and diplomat (2nd ed). New York: American Council on Education: Macmillan.

Wolverton, M., \&Gmelch, W. H. (2002). College deans: Leading from within. The American Council on Education and The Oryx Press.

Wolverton, M., Gmelch, W. H., Montez, J., \&Nies, C. T. (2001). The changing nature of the academic deanship. (ASHE-ERIC Higher Education ReportNo. Volume 28, Number 1). Retrieved from

http://www.eric.ed.gov/ERICWebPortal/detail?accno=ED451760

Wolverton, M., \& Gonzales, M. J. (2000). Career paths of academic deans. Presented at the Annual Meeting of the American Educational Research Association, New Orleans, LA. Retrieved from http://eric.ed.gov/?id=ED442447

"ISO 9000 Essentials." ISO 9000 - Quality Management. International Organization for Standardization. n. d. Web. 30 Jan 2011. http://www.iso.org/iso/iso_9000_essentials

“ISO 9001:2008”, Fourth Edition, November 15, 2008

$x x x x x x x x-----x x x x x x x x$ 